\title{
Shared Voices, Different Worlds \\ Process and product in the Food Dignity action research project
}

Gateways: International Journal of Community Research and Engagement Vol 7 (2014): 116-128 (C) UTSePress and the authors

ISSN 1836-3393
Christine M. Porter

University of Wyoming

\section{Hank Herrera}

Center for Popular Research, Education and Policy \& (until Dec 2013) Dig

Deep Farms \& Produce

\section{Daryl Marshall}

East New York Farms!

Gayle M. Woodsum

Feeding Laramie Valley
La Via Campesina, the international peasant movement, declared that 'the people hold thousands of solutions in their hands' for creating just, democratic and sustainable food systems (La Via Campesina 2010). Given peak oil, peak soil, and a tipping point for atmospheric carbon dioxide concentrations (Montgomery 2007; Bakhtiari 2004; Lemonick, 2008), we are likely to need all of those solutions and thousands more in order to feed our seventh generation.

Over three dozen people from five community organizations, three academic institutions and one non-profit 'think and do' organization are collaborating on a five-year US-based action research project called Food Dignity to identify, support and assess such solutions. We come from different worlds personally, socioculturally, organisationally - but are sharing our stories, experiences and expertise. In this article, four of us outline our strategies, struggles and successes in our first three years of trying to share voices by bridging worlds in our work together for Food Dignity.

Our project, 'Food Dignity: Action research on engaging food insecure communities and universities in building sustainable community food systems', was awarded US $\$ 5$ million for five years from the USDA National Institute of Food and Agriculture for the Agriculture and Food Research Initiative. We started in April 2011.

Food Dignity builds on four premises:

-Three billion people (43 per cent of the world's population) suffer from malnutrition

-The industrial food system is not sustainable

-Community-based local and regional food systems offer ethical and practical solutions

- Governments and philanthropists should invest in these community-based systems and learn from those leading and implementing these initiatives.

The Food Dignity team envisions a society where each community exercises significant control over its food system 
through democratic negotiation, action and learning in ways that nurture all people in current and future generations. The team is collaborating on research that will help find the ways to get there.

The five community organisations involved with Food Dignity have been working on creating just and sustainable food systems for a collective 32 years. The aggregate food movement and social justice organising experience of key leaders in those community efforts exceeds a century.

Academic partners bring tools from their disciplines, including public health nutrition, anthropology, development sociology, education, economics, agroecology, medicine and planning. However, the project's knowledge foundations, research questions and guiding values are mainly by and for the community partners. In that sense, this is not a transdisciplinary project but a supra- or post-disciplinary one. It also is radically axiological; that is, we use the ethical framework of the vision stated above and of 'dignity' as both a process and an outcome to guide our paths to knowledge production (Pelletier et al. 2013; McDonald 2004; Wilson 2008; Jacobson 2007; Hicks 2011).

Our primary objective is to identify, develop and evaluate scalable and equitable strategies for organising sustainable community food systems to ensure food security. Our approaches include:

-Developing, sharing and analysing the case studies of the work being done by our five community partners

-Each community testing and co-evaluating a US\$65000 per year 'organising support package', including funding for a community organiser, community-led research, travel and mini-grants

-Documenting practices, outcomes and impacts of selected actions and strategies, including mini-grants and home and community food gardens

-Conducting a sixth case study of the project collaboration itself to inform how academic partners can best support and learn from and with the community work.

This article presents the personal experiences of three community-based participants and one academic as part of this 'sixth case study' of the Food Dignity action research collaboration. We each write a section below, describing strategies, struggles and successes in the first three years of working together on the Food Dignity project. Though we come from different worlds personally, socioculturally, organisationally - by contributing our stories, experiences and expertise, we share and yet also retain our individual voices. As the Zapatistas wrote:

Dignity is a bridge.

It needs two sides that, being different, distinct and distant become one in the bridge

Without ceasing to be different and distinct, but ceasing already to be distant (Zapatista March of Dignity, cited in Bühler 2002). 


\section{FEELING MY WAY INTO THE SIXTH CASE STUDY (HANK)}

Christine and I first met, electronically, in 2008 through a childhood obesity prevention list serve that she started. She and I have been discussing how to build local food systems and how to create equitable and relevant action research relationships ever since. When the opportunity to apply for the USDA grant arose, we agreed to collaborate. For the first three years of the project I had a duel role, one as a community-based researcher supporting the five community partners and the other as the general manager of one of those partners, Dig Deep Farms \& Produce. As of 2014, I serve as lead investigator for the sixth case study.

From the very start of the Food Dignity project, community members have had what we may call 'close encounters of the oppression kind' with academic partners.

The project started in April 2011 and we held our first Food Dignity face-to-face meeting that May. In planning this meeting, Christine and I talked about how to create a learning environment where community partners and academics could learn about each other and begin to build the collaborative, mutually supportive relationships that we would need as the energy to drive the project. As Christine put it in her opening presentation, the top two goals of the meeting were '(1) to care about telling our stories, individually and collectively and (2) to trust that we at least might be able to do it well together'. We both knew that community residents and academics lived in different worlds. By the time we were planning this meeting, Christine and I had spent three years grappling, often heatedly, with those differences. We talked by phone and in several face-to-face meetings to discuss, question, clarify, and slowly and deliberately move toward understanding. We did not cease to be different and distinct, but ceased to be distant.

The project's first face-to-face meeting was only three days long. Among people from different worlds, this was hardly enough for a slowly unfolding conversation that fosters mutual learning and respect, especially in the face of entrenched sexism, racism and classism and fraught town-gown relations. Many partners were coming from communities with long histories of trauma.

Historical trauma is the 'cumulative trauma over both the life span and across generations that results from massive cataclysmic events', such as enslavement, segregation, and physical and cultural genocide (Brave Heart 1999, p. 111). The term originated in relation to Native Americans but applies to African Americans, Latinos, Asian Americans, Pacific Islanders, indeed all groups oppressed by colonial practices of domination, extermination and exclusion. Community members - especially those born and raised in poverty and in communities of colouroften suffer from the consequences of historical trauma, such as post-traumatic stress, depression, poor physical health, substance abuse and domestic violence. 
Community members talking among themselves may share their personal stories but rarely, if ever, share those stories with academics, in particular white academics. How does one tell those stories? In my case, how do I talk about what it felt like to have the 4th grade teacher talk about my people as 'digger Indians'? How do I talk about the cute 10th grader who told me I could not walk her home because her university professor father didn't want her to go out with Mexicans? How do I tell the story of the old white woman who refused my visit - as a medical professor in a white coat on rounds with students in tow - because, in her words, 'I don't talk to no beaner'? How do I explain discovering as an adult that in fact I am not Mexican but Ohlone, a Native California tribe? That I didn't know that because my father never told me, probably because, like many Ohlone, his parents became 'Mexican' to protect our family from the California policy of exterminating native people? (In 1851 and 1852, the California legislature authorised over US $\$ 1$ million in payments to white men who could show they had murdered an Indian. The state was eventually reimbursed by the federal government (Laverty 2003).)

Every community member has his or her own stories, suffers from the personal and emotional impact of historical trauma, and may contain an explosive rage toward whomever appears in his or her world representing those forces that caused the pain.

And so all of the Food Dignity partners - community and academic, white and people of colour - met in May 2011; some on guard, wary, uncertain, insecure. Some with deep commitment to fighting for justice in our neighbourhoods. Some knowing that life on our streets is hard, sometimes cold and extremely mean, where young friends and co-workers have buried their young friends and co-workers. Some knowing that every day is a struggle to keep on going in spite of not having enough of the resources needed to do the job. And others smiling, happy, polite, curious, eager, interested, and sharing lovely stories of leisurely scholarship, trips to distant lands, meetings attended, papers presented, accomplishments, ideas, and of course knowledge - real knowledge, authentic knowledge, scientific knowledge, dominating knowledge, paramount knowledge - the reality-making knowledge that trumps anything those of us from the streets might have to offer.

At that meeting in May, and in the collision of these dense and opposing worlds, the predictable happened: it all blew up. And just to make sure, we repeated the collision twice more, in October 2011 and May 2012. Though in some technical ways the project was making significant strides in the research, the team largely remained different, distinct and distant. To put it more colloquially, each time, it blew up. Community members - mostly people of colour and mostly poor - felt patronised by the academics. And in some cases, the academics displayed the most stereotypical patronising condescension possible. Academics felt hurt and bruised by the hostility they felt from community members, all 
the more so if they had been expecting to be considered 'the good guys'. And, in some cases, community members said hurtful things.

The community members wanted to address issues of race, class, power and privilege. The team agreed that we needed to bring in a facilitator to do anti-racism training in May 2012. Some white people felt judged and distressed.

Community members reported that they had experienced all of the usual forms of oppression at each community site, such as structural racism, subtle expressions of racial prejudice, sexism, cultural insensitivity, and assumptions of power and privilege. Over three years the catalogue has grown and have been enacted in ways unique to place. For example, in Laramie, one way academic privilege manifests is Christine frequently being credited for Gayle's work.

All of the community partners and most of the academic partners have come to understand that this project requires us to confront the exertion and exercise of academic power and privilege. The goal of community partners is to exert our own community power and privilege and to assert the legitimacy of knowledge and wisdom that emerges from our daily life experience and the everyday learning that we need simply to survive. We now see this work as flipping relationships of power and privilege between community and campuses. Learning from Gayle's leadership in the Community Campus Partnership for Health's Community Network for Research Equity and Impact, Gayle, Christine and I are establishing even more substantial guidelines and rules for engaging academic partners.

Community leaders don't easily let in outside researchers. We don't let others tell our stories. We consider outsider narratives forms of extraction and expropriation of our knowledge and wisdom - community wealth that we will share at our discretion.

These elements of the project quickly became 'the sixth case study'. The sixth case study research question is: how can and should universities support communities in building secure, sustainable and equitable food systems and in learning from that work? We are answering that question (and it's opposite, how not to do it) through documentation and evaluation of our collaborative work on the Food Dignity project.

The sixth case study builds on the following beliefs, proposed by community partners during development of the grant application and largely embraced by Christine in its design:

-Experiential knowledge and contextual wisdom reside in communities. But communities lack resources, power and privilege

-Academies have a concentration of resources, expertise, power and privilege

-Change will occur with a shift in resources, power and privilege through the Food Dignity support package for community organising, community research, mini-grants and technical assistance. 
We have already learned that the 'support package' is needed but by itself is not enough to create equitable communitycampus relationships in this project. We are now testing additional financial and leadership strategies to achieve the right balance. The resource gaps in our communities are profound. From a public health perspective, social inequities lead to health disparities; for example, life expectancy on the Wind River Reservation is only 49 years (Williams 2012).

Through the sixth case study we hope to expand what counts in research, as shown in Table 1 (prepared by author Christine Porter).

Table 1: Expanding what counts as knowledge generation

\begin{tabular}{lll}
\hline & Dominant research narrative & Research in Food Dignity \\
\hline Expertise & $\begin{array}{l}\text { Professionals, academics, } \\
\text { institutions, study }\end{array}$ & $\begin{array}{l}\text { Also citizens, communities, } \\
\text { associations, experience }\end{array}$ \\
\hline Ethics & $\begin{array}{l}\text { Last: used to apply knowledge } \\
\text { gained about truth }\end{array}$ & $\begin{array}{l}\text { First: used to decide what we want } \\
\text { to know and how we will try to } \\
\text { find it out }\end{array}$ \\
\hline Knowledge & Must be written & Can also be oral, visual \\
& Generalisable & May be transferrable \\
& Scientific method & Stories \\
\hline
\end{tabular}

The Food Dignity team is now using the following strategies to improve collaboration and equity between the community and academic partners:

- Pushing academics to work from the heart and soul, not just the head: 'If research doesn't change you as a person, then you aren't doing it right' (Wilson 2008); 'Dignity is not something that one studies, it is something that one lives or dies. Something that doesn't walk in the head, something that walks in the heart' (Zapatista communications on dignity, cited in Bühler 2002)

- Spending time together during Food Dignity team meetings, site visits, and conferences. We talk face to face as much as possible

-Writing papers together (such as this one), presenting together and designing research together

-Sharing financial resources, even if the shares are still not yet equitable. Most recently, the University of Wyoming and Cornell University reallocated $\$ 200000$ from their budgets to support community-led action research and dissemination

-Working to share leadership of the project. Recent strategies for this included expanding the number of community-based partners who are paid members of the project-wide team and hiring an outside facilitator for our most recent team meeting in May 2013 (in the course of which, we may have become less distant).

After three years in this five-year action research project, several themes have emerged from the sixth case study:

-Food Dignity is a project for academics, but this work is life and death for communities

-Some academics doing this work report feeling 'fringe' within the academy. But this 'fringe' is relative: the academy and the academics within it are well protected compared to the everyday 
life and death struggles of the truly marginalised groups represented by the community partners

-Community members' radically varied locations and life courses, enmeshed in gross social inequities, create different lived realities. We are tackling the tall tasks of accounting for, acknowledging, and (as much as possible) bridging these realities in the struggle for the Food Dignity project and, more importantly, for living a reality of food dignity for our communities.

\section{EAST NEW YORK FARMS! (DARYL)}

East New York Farms! has been around since 1998. It was birthed out of community need for open space and activities for youth. Residents met with non-profit organisations and the Pratt Institute to talk about what could be done. They realised that vacant lots were left empty due to the city's financial problems of the 1970s, as well as white flight, redlining and the crack epidemic, and this opened the door for East New York Farms! to start up urban gardens in our community's abandoned spaces.

East New York has been neglected because of its location, as well as the colour of its population. This burden of blight can be a deterrent to hope, and cause people to believe nothing is going to change. Clearly, that is not the motto of East New York Farms! staff and members.

Plans and preparation for unused land and talent created a place where food could be grown naturally and community youth, seniors and adults could work, learn and socialise together. These tangible things have carried us along for over 15 years so far. It has not been without hardship and struggle: pain caused through discriminatory practices and good ole statistics that say one is more likely to perish here than in perhaps almost any other area of this great metropolis.

Some say statistics don't lie but they surely don't tell the whole story of 180000 and counting. My community boasts a head count greater than some cities. Large groups of people in an overcrowded, publicly and privately disinvested area can be a cause for concern. Our bordering neighbourhoods have not fared well either.

Our allegiance with Food Dignity and our practices and collective goals have gelled well. This has given us space to share our story and be inspired by what is happening not only in urban settings but rural as well. Monetarily we have been able to seize the creativity and resolve of our community and fund action in the form of mini-grants.

I have been personally moved by being able to help manoeuvre the vehicle known as the Food Dignity research project throughout the neighbourhood of East New York, Brooklyn. The process has given me and our entire organisation many opportunities: tracking the yield of what our community grows is an empowering and a concrete way of showing ourselves and others we can grow food. Writing our own story as a 'case study' reminds us of our humble beginnings and keeps us focused on 
sustainability. Having a national, and now international, platform to share our successes and challenges helps keep us sharp and grateful for the opportunity. I would like to see and help create more opportunities for people of colour to take a role in food justice work - because our lives directly feel the impact of food inequities.

\section{FORGING A COMMUNITY PATH FOR RESEARCH THAT MATTERS (GAYLE)}

Every community project operates within a context of history and experience. The historical reality of research for most communities is that of an unmanageable beast that roars into town in the name of 'it's for your own good', intruding on citizens' time, good grace and vulnerabilities. Once valuable data has been extracted from the process using financial and other supportive resources the community has little or no access to, off fly the lessons learned to be turned into publishing opportunities for 'scholars'.

I came into my work with the Food Dignity research project angry and sceptical. As a long-time community organiser for social change, I was working with Feeding Laramie Valley (FLV a new grassroots program addressing food sovereignty issues in southeastern Wyoming), when I was invited to provide input to the Food Dignity grant application, and to include FLV as one of the five participating community partners in the project. The design of the project, the inclusion of community input at the start, the potential for a real community voice and ownership of research, and the financial support package promised to my community nudged my anger and scepticism over all the abhorrent historic truths just enough to get me to agree to sign on to this thing called the Food Dignity research project.

But history and scepticism are not easily overcome. This work - the work of trying to achieve authentic partnerships between community and academia - is incredibly difficult. Feeding Laramie Valley is passionately dedicated to and protective of community-led self-determination and control when it comes to doing a better job of feeding ourselves and each other in a way that is equitable, just and sustainable. We know there are questions to be asked, answered and analysed if we are to make positive change. We also know that we as a community must be in charge of the process to ensure true long-term benefits to all our citizens. These are not always concepts easily grasped by the academic machine that survives and thrives on being in control of this kind of work.

As the Food Dignity project team members began to work together, the community partners (including those of us at Feeding Laramie Valley) challenged the academic status quo, demanded power behind our loud voices, and took part in difficult conversations with the academic and administrative contributors to the project we'd signed on to.

As glorious as the potential for something different seemed to be, I couldn't shake the old pain of past wounds incurred in 
the name of community research, nor the fresh pain caused by insensitive comments and resource inequities that popped up as the academic and community threads of the Food Dignity project tried to find a way to blend into a meaningful, cohesive effort.

For nearly two years, the core premises kept me hanging on when the day-to-day practice of this community-university partnership faltered. More specifically, it was the willingness of the academic core team, led by Christine Porter, to hear community challenges without turning away or digging in (at least not completely or permanently) that kept me hanging on. The guiding premise of the project - that the answer to food security and dignity lies in sovereign community control of our food systems - which I gradually recognised as being genuinely aligned with my own and that of my community, did not waiver. It held up to our struggles. Food dignity as a premise and Food Dignity as a research project are both steeped in recognising that community people hold the knowledge and ability to ask the right questions and find the right answers to their own needs.

Little by little, as all the project team members continued to struggle but did not turn away from each other, I began to see metaphor in the food sovereignty work of Wyoming (harsh weather, geographic isolation, short growing season) and this unusual grant I'd attached us to.

From a technical point of view, I have found radical practice possible in the fact that we have five long years of grant-supported project time and flexibility within the project design to make changes essential to authentic partnership work (such as making language changes to reflect community activist language rather than language of the academy, and the ability to shift grant funds provided to the community between budget lines).

From a social justice point of view, I have found hope and inspiration in these unexpected resources that connect five disparate communities across geographic and cultural boundaries often enough and long enough to create relationships that teach, support and guide us toward a different kind of future.

\section{RECLAIMING RIGOUR WITH DIRTY HANDS AND OPEN HEART (CHRISTINE)}

My first memory is of a ferry journey to Newfoundland to visit my great grandmother about 40 years ago. From the boat, the water beckoned as the biggest swimming pool I'd ever seen. I must have shared this with my father, because he warned me that the water was full of jellyfish (his story) or sharks (my story). Either way, for me the moral of this story was that the water went from being beautiful to terrifying, and I've been afraid of natural bodies of water ever since. Thus, a cliff jump into such water feels scary and dangerous. However, when I was a Peace Corps volunteer in Fiji in the 1990s, I learned to follow the leaping lead of local youth. I found that cliff jumping turned out to be fun and exciting. 
That said, my next felt-daring-for-me leap came only in 2006, when I gave up the control and predictability of doing an armchair dissertation at Cornell University and, instead, threw myself into a new community-based health project. I didn't know what the research would be, but hoped that if I kept showing up and helping out, the research questions - and answers - would eventually emerge. It felt like jumping off a cliff. But it landed me with an amazing set of mentors and friends, and the framework for the Food Dignity project. Through that work I met Jemila Sequeira, my first organising and anti-racism mentor, and organiser of the Whole Community Project for food justice that was born out of that community-based health effort. I also met Hank, as he describes, through my attempt to network such efforts. The Whole Community Project is now one of the five community partners in Food Dignity, as is the Dig Deep Farms \& Produce project that Hank helped to found.

Until my last year as a PhD student at Cornell, I had proclaimed that I would never become an academic. However, in the end, I decided that as an activist academic, rather than an academically minded activist, I could bring more money to social justice work and help to amplify the wise voices of people doing that work to a wider and a powerful audience. (Plus, I was a mediocre activist apprentice to Jemila, at best.)

However, I never once thought I would have the luxury, and the burden, of having US $\$ 5$ million over five years to further that mission. I was terrified and excited at our first team meeting of Food Dignity partners three years ago. My learning curve was almost vertical and I spent a lot of time being afraid.

Today I am, by necessity, a new kind of brave, because I spent 2013 battling stage 3 breast cancer. With this new benchmark for risk, I ask myself: what have I been so afraid of?

One lesson I've learned is that the worst possible place for leadership and good decision-making is one of reactive fear. I had lots of reactive fears. I was afraid of USDA discontinuing our funding. I was afraid of academic partners - especially at Cornell of thinking this project was too ambiguous, too slow, too hard, and not enough like research. I had a nightmare that David Brooks the New York Times columnist - told the president of a foundation I was working with that what I do is not research, it is storytelling. (Funnily enough, this year Brooks wrote a column about the importance of storytelling in creating and understanding knowledge (2013).)

Most of all, I was afraid that I'd disappoint the community partners and mentors, especially by being too racist, too blindly arrogant and not radical enough to do this work. I was afraid that I, and this project, would repeat the usual crimes in communitycampus research - including co-opting wisdom, knowledge, credit and funding. I was also afraid that we would get the stories of the community food work wrong.

In discussions about a new action research pilot effort that grew out of the Food Dignity collaborations in Wyoming 
(a project we call 'Growing Resilience'), Gayle and I discussed whether the word 'rigour' in research was reclaimable. Gayle said she felt it was used as a tool with which to bash her and other community research partners over the head. I argued that our Food Dignity collaboration is working to illuminate how false this dichotomy of rigour versus participation is; that for research involving communities, rigour requires participation, or we'll get the story wrong. For example, the day before, Gayle, Wind River Indian Reservation partners, and my University of Wyoming team had been reviewing and rewriting survey questions for Growing Resilience. A community partner revealed that when she wasn't comfortable with wording in surveys she administered, she would simply reword the question. Therefore, eliminating the co-design step of those surveys endangered the rigour of that research. (This truth argument is in addition to the 'radical axiology' ethical ones for participatory research; without it, the process and likely also the research questions will be wrong.)

Recently, a participatory research paper reinforced Gayle's rigour-as-bashing-tool case, by stating that their 'aim was to maintain rigorous research, to follow a "clean mind" approach to research, but maintain principles of community participation which necessitate "a dirty hand"' (Makhoul et al. 2013). Firstly, minds are never 'clean'; they are filled with our life experience, and research rigour requires that we account for, not ignore, our world views (Harding 2000). Secondly, for research relating to community concerns, the 'dirt' is part of the story. Sanitising hands means destroying key data. Thirdly, what about the heart?

I owe Hank a lot of credit for holding me back from making important project decisions from that dangerous hole of reactive fear until I finally (mostly) found a better way. With the help of time, study and friends (including those on the Food Dignity team), I have been climbing out of that hole - embracing those fears along the way.

I have discovered that acting with courage is so much easier than acting out of fear and, with some irony, makes my fears much less likely to be realised. I now know that, when I most want to turn my back, I need to pry open my heart. When I most wish to squeeze my eyes shut, I must force myself to witness. Instead of defending, I should listen and learn. And never, ever, suppress my red flags.

Just as examples, here are two flags I should not have ignored.

In my very first memo to the Food Dignity team I defended the indirect costs the universities take: ' $12 \%$ might sound high to community people, but it is well below the circa $50 \%$ that is a standard university rate, and the $28 \%$ allowed by USDA'. Share and discuss - yes - but why defend? I was so deep in my reactive fear hole that I was being proactively defensive, and about something I had no wish to defend.

About a year later, in our first collaborative Food Dignity conference presentation, I submitted all the names of the team 
members who were participating. The conference organisers came back and said we could list only two. After one weak attempt at getting an exception, I ignored a red flag that I felt and listed myself and Hank as the leads in the project. As the conference drew near, the flag became more like a fire alarm and I wanted to run - even though I couldn't articulate why. At the conference, Jemila and Gayle went from being warm with me to giving me the cold shoulder, after having seen the program, which did not list all the co-authors. They each tried to help me understand; and now I can glimpse how my behaviour represented one of the big risks for Food Dignity - that academic partners will appropriate and colonise and take credit for the work and wisdom of community partners.

In a poster that some of us did for a Community Campus Partnerships for Health conference, we finally named some ways that Food Dignity perpetuates inequity (for example, all the academic partners are white and receive much better fringe benefits) (Woodsum et al. 2012). This was so much easier than defending them.

I still have a long way to go, as my co-authors could tell you. But I am not alone among the Food Dignity academics, I think, in learning to do this work with courage, working from an open-hearted place of love and hope instead of acting from fear and feigned detachment. I am also learning that coming to the research from this more 'true' place means that community partners are more interested in working with us to identify and share 'true' answers in our research collaborations. In other words, working from the heart, with love and courage, leads to research that is not only more ethically 'right' (and way more fun), but is also more rigorous.

Love, hope and courage have been my talismans on this journey of learning how to do social justice action research in community-academic collaborations. I have also learned that all of these feelings flourish when I work from a place of gratitude.

I am grateful to Hank for teaching me to work from the heart before the head; to Gayle for her mentorship in leadership and in working with gratitude; and to Daryl whose wisdom, tenacity and courage teach me hope.

Most of all, I am grateful to every one of the over three dozen people working in this project who struggle through the collision and collaboration of voices and worlds to reduce the distance - the distance between us, and the distance from here to food dignity.

\section{ACKNOWLEDGEMENTS}

Food Dignity (www.fooddignity.org) is supported by Agriculture and Food Research Initiative Competitive Grant no. 2011-6800430074 from the USDA National Institute of Food and Agriculture.

The Growing Resilience pilot is supported by grants from the National Center for Research Resources (5P20RR016474-12) and the National Institute of General Medical Sciences (8 P20 GM10343212) from the National Institutes of Health. 


\section{REFERENCES}

Bakhtiari, A 2004, 'World oil production capacity model suggests output peak by 2006-07', Oil and Gas Journal, vol. 102, no. 16, pp. 18-19.

Brave Heart, M 1999, 'Oyate Ptayela: Rebuilding the Lakota Nation through addressing historical trauma among Lakota parents', Journal of Human Behavior in the Social Environment, vol. 2, nos. 1-2, pp. 109-26.

Brooks, D 2013, 'What data can't do', The New York Times, 18 February, p. A23.

Bühler, U 2002, 'Participation "with justice and dignity": Beyond the "new tyranny"', Peace, Conflict \& Development, vol. 1, no. 1, pp. 1-16.

Harding, S 2000, 'After the neutrality idea: Science, politics, and "strong objectivity"', in M Jacob (ed.), The politics of Western science, 1640-1990, Humanity Books, Amherst, NY, pp. 81-101.

Hicks, D 2011, Dignity: The essential role it plays in resolving conflict, Yale University Press, New Haven, CT.

Jacobson, N 2007, 'Dignity and health: A review', Social Science \& Medicine, vol. 64, pp. 292-302.

La Via Campesina 2010, 'Via Campesina Declaration in Cancún: The people hold thousands of solutions in their hands', press release, viewed 30 July 2013, http://viacampesina.org/en/index.php/actions-and-eventsmainmenu-26/-climate-change-and-agrofuels-mainmenu-75/984-viacampesina-declaration-in-cancun-the-people-hold-thousands-of-solutions-in-their-hands.

Laverty, P 2003, 'The Ohlone/Costanoan-Esselen Nation of Monterey, California: Dispossession, federal neglect, and the bitter irony of the federal acknowledgment process', Wicazo Sa Review, vol. 18, no. 2, pp. 41-77.

Lemonick, M 2008, 'Global warming: Beyond the tipping point', Scientific American, Special Edition, vol. 18, no. 4, pp. 60-67.

Makhoul, J, Nakkash, R, Harpham, T \& Qutteina, Y 2013, 'Communitybased participatory research in complex settings: Clean minddirty hands', Health Promotion International, 19 July 2013, online in advance of print, viewed 9 December 2013, www.ncbi.nlm.nih.gov/ pubmed/23872385.

McDonald, H 2004, Radical axiology: A first philosophy of values, Rodopi, Amsterdam.

Montgomery, D 2007, Dirt: The erosion of civilizations, University of California Press, Berkeley, CA.

Pelletier, D, Porter, C, Aarons, G, Wuehler, S \& Neufeld, L 2013, 'Expanding the frontiers of population nutrition research: New questions, new methods, and new approaches', Advances in Nutrition: An International Review Journal, vol. 4, no. 1, pp. 92-114.

Williams, T 2012, 'An Indian reservation in crime's deadly grip', The New York Times, 3 February, p. A1.

Wilson, S 2008, Research is ceremony: Indigenous research methods, Fernwood Publishing, Black Point, Nova Scotia, Canada.

Woodsum, G, Sutter, J, Herrera, H \& Porter, C 2012, 'Food Dignity', poster presented at the Community Campus Partnerships for Health, Community Partners Meeting, Washington, DC, 9 December. 